\title{
The folly of vulnerability beyond epistemic injustice and the power of knowledge: A vulnerable praxis of thinking (practical theological ethos) in global conversation
}

\author{
Author: \\ Johann-Albrecht Meylahn ${ }^{1}$ \\ Affiliation: \\ ${ }^{1}$ Department of Practical \\ Theology, University of \\ Pretoria, South Africa \\ Note: \\ This article is published in the \\ section Practical Theology \\ of the Society for Practical \\ Theology in South Africa.

\section{Correspondence to:} \\ Johann-Albrecht Meylahn \\ Email: \\ jmeylahn@lantic.net

\section{Postal address:} \\ PO Box 14885, Lyttleton \\ 0140, South Africa \\ Dates: \\ Received: 20 July 2012 \\ Accepted: 27 Aug 2012 \\ Published: 04 Dec. 2012 \\ How to cite this article: \\ Meylahn, J-A., 2012, 'The \\ folly of vulnerability beyond \\ epistemic injustice and the \\ power of knowledge: A \\ vulnerable praxis of thinking \\ (practical theological ethos) \\ in global conversation', \\ HTS Teologiese Studies/ \\ Theological Studies 68(2), \\ Art. \#1304, 5 pages. \\ http://dx.doi.org/10.4102/ \\ hts.v68i2.1304
}

C 2012. The Authors. Licensee: AOSIS OpenJournals. This work is licensed under the Creative Commons Attribution License.
The diverse and divided South African context of post 1994 is the context in which the texts of reality are read (knowledge is created and reality is interpreted). This particular diverse and pluralistic reading with and within the context is sensitive to the voice of the other and thus provides an inbuilt deconstruction thereby offering a vulnerable practical theological openness to the global conversation beyond certainties. This holy folly of vulnerability was explored with regards to South Africa's practical theological contribution to the global conversation.

In South Africa - in a plural and multi-lingual context - one is daily confronted with the other from a different racial, cultural, linguistic or social economic group. In a diverse country such confrontation is inevitable and cannot be ignored as is possible in some mono-cultural countries where the dominant majority comes from the same cultural-linguistic background. The other cannot be ignored, specifically after 1994 with the political ideological move towards non-racialism and embracing diversity. In the 'New South Africa' the other's position has to be taken seriously because the chances are that one depends on the other in some way or other. The employer, colleague or person working on the other side of the counter of the local service provider might be from a different racial, cultural, or linguistic background. For the encounter to be 'successful' the other needs to be taken seriously. One's own as well as the other's Dasein [being-there] can be described as Heidegger's Being-in-the-world (see Caputo 1993:12) and specifically in South Africa it can be described as Being-in-South-Africa. In other words, one's own Dasein in South Africa is a combination of the various beings (objects/things/persons) in my South Africa, but seen and received within a specific horizon (Being) and thus I refer to it as Being-in-South-Africa.

One's Being-in-South-Africa is a linguistic event (Ereignis), which means that how one views the various things of one's world is determined by one's cultural-linguistic context. In a multi-lingual context there is thus a clash of various differing kinds of Being-in-South-Africa as South Africa is a country with various worlds.

Taking the other seriously translates into taking the other's Being-in-South-Africa seriously, if one wants to live together in the same space (country). The other's Being-in-South-Africa challenges one's own Being-in-South-Africa as it exposes one's Being-in-South-Africa and relativises it with regards to the others' Being-in-South-Africa. In a plural context the Dasein of the other exposes and questions one's own Dasein, leaving one in a state of vulnerability. Wolfgang Welsch describes this encounter with an other opinion or position as having the following possible results which I have adapted to the specific South African context:

- The other's Being-in-South Africa does not apply to one's own Being-in-South-Africa at all because of a conceptual misunderstanding that they are two irreconcilable positions.

- The other's Being-in-South-Africa seems valid, but only within the framework of the other's Dasein and thus it challenges one's own framework or Being-in-South-Africa.

- You need to investigate further if one is uncertain as to the extent of the applicability of the other's position with regard to your own (Welsch 2008a:p. 5 of 16).

Therefore, irrespective of the outcome of such an encounter, one's Being-in-South-Africa has been challenged and opened to other possibilities thus leaving one in a state of vulnerability. As it is against human nature to remain in a state of vulnerability one has two options - either fight or flight, but both these options are essentially the same. One can either flee from the other by seeking to ignore the other's Being-in-South-Africa or one can fight the other's Being-in-SouthAfrica and deny the other a right to the shared space. Both these options are essentially the same as they both work from the premise that one's Being-in-South-Africa is correct and the other's Being-in-South-Africa can be ignored or destroyed, thus making one's own Being-in-SouthAfrica absolute. This fight or flight response is seen in South Africa in various forms of culturallinguistic antagonism through which cultural-linguistic ghettos are created. A ghetto mentality is 
where one's Being-in-South-Africa is stated as absolute and no other views are tolerated so much so that one denies the other a right to Dasein (a right to be there - here in South Africa). This view is expressed in various forms of religious, cultural or ideological fundamentalism and explains why fundamentalism is flourishing in South Africa.

The more politically correct response to this vulnerability would be to take on a liberal position where diversity is tolerated. On what basis is such tolerance of diversity possible? It is possible by constructing a new Being-in-South-Africa that includes diversity and more specifically tolerance of diversity. If one places this into Lacanian discourse theory (1991) one could argue that what is necessary is to develop a new master discourse where tolerance is in the position of truth.

Wolfgang Welsch and Calvin Schrag developed their theories of transversal reasoning as one possibility to create a new space for plurality, that is to say creating sufficient reason, such as transversal reasoning, for Being-in-a-diverse-world. Transversal reasoning is empty of specific content and thus as a pure logical space it is open for the reasonable conversation between various rationalities (see Welsch 2008a, 2008b \& Schrag 1992) or various kinds of Being-in-the-world. It is the necessary reasoning strategy for Being-together-of-diverseforms-of-Being-in-the-world.

Is transversal reasoning really so pure or does it open this space for the power struggle between competing rationalities, or does it itself become a powerful epistemic discourse and therefore a form of epistemic injustice, as Michel Serres argued concerning the wolf and the lamb in his book Hermes (Serres 1982:15)? The wolf always drinks upstream from the lamb even if the stream is the stream of pure logic. If the stream from which the wolf and the lamb drink is the stream of pure logic, as Welsch tried to argue, it remains a stream where the strong know best and therefore it opens this transversal reasoning of pure logic to the misuse of power as the dominant discourse determines the 'pure' logic, or the dominant discourse becomes 'pure tolerant logic'.

Is this not what is happening with the liberal West where diversity is tolerated as long as it does not disturb the dominant economic interests? You can be as diverse as you wish, you can follow any fashionable fad, unless your fad questions the basic working of the market economy and then your eccentricity will be labelled terrorist.

The challenge is to remain in this position of vulnerability or homelessness, as Slavoj Žižek argues, 'homelessness remains irreducible; we remain forever split, condemned to a fragile position between the two dimensions, and to a "leap of faith" without any guarantee' (Žižek 2006:9). He continues by asking if this is not what Hegel proposed - that the new home of philosophy is in a way homelessness itself as the very open movement of negativity (Žižek 2006:9)?

In this article I shall seek to unpack this irreducible homelessness (vulnerability), not as something that should be overcome, but as something that can be embraced without it becoming once more a master discourse where in the position of truth, now is vulnerability. This radical homelessness (vulnerability) is the absolute absence of a transcendental home (Heimat) to which we strive and thus it can be compared to a form of radical immanence where the search and longing for a transcendental meta-discourse is given up and immanent homelessness and vulnerability is all there is. To say it within the context of Jacques Derrida's thinking: all there is, is the text or context (see Derrida 1997a:158) and this text or context is characterised by différance - radical openness towards the trace of the other as the faint memory of the past never present and a future that is always still to come (see Derrida 1982:12, 21). This means not seeking a transcendental meta-discourse, but remaining in the vulnerable position of being questioned by the other, without transcending that vulnerable position via recourse to a transcendental discourse where unity or identity is again achieved, but on another plane like Kant's Weltbürgergesellschaft (see Žižek 2006:9). On this other plane or meta-level the differences are sublated into a greater identity of reason, for example transversal reason of a new space: Weltbürgergesellschaft.

François Laruelle (2010) accuses Derrida of doing exactly that: of thinking the identity of difference on a meta-level. In other words, on the level of text and presence (other) there is a radical abysmal difference as there is only text as différance, yet on the meta-level of deconstruction there is in a sense an identity. This identity is on the meta-level of messianic hope, but without Messiah (Derrida 2002:56) or the infinite dream of justice and democracy always still to come. Thus there is impossible possible identity in the dream of a just and democratic Weltbürgergesellschaft that has never been present and that is always still to come. In this impossible possible identity vulnerability is sublated at a meta-level.

Laruelle seeks a radical immanence of vulnerability that is not sublated at any meta-level of speculation (see Laruelle 2003:173) of, for example, Derrida's democracy and justice to come (see Derrida 1997b). This radical immanence or radical praxis can be interpreted as a radicalisation of Derrida's infamous statement that there is no outside text (Derrida 1997a:158). There is no other or totality or holism that can minimise the vulnerability via an inclusion into a new whole or identity of some kind, not even the identity of pure logic as Welsch (2008a:p. 8 of 16) proposes, or the identity of a democracy still to come. Laruelle (2010) accuses Derrida of not remaining true to his statement by including différance into a new identity on a meta-level. The new identity is not a form of classic correlation between one and other as in Derrida there is an absolute abyss, the other remains tout autre. Yet, Laruelle (2010) argues that on a meta-level, namely on the level of deconstruction, there is a new identity. Laruelle refers to this overview position that is only available to philosophers as specularity (Laruelle 2003:173), namely seeing différance, the trace and the haunting of the other becoming part of a greater narrative of deconstruction inspired by justice and democracy still to come, thus reducing the vulnerability by including vulnerability into a the noble narrative of justice and democracy always still to come. Therefore what is - the text - is related to the wholly other via the haunting of the trace. The various incarnations of democracy and justice are 
haunted by what is other, thus opening what is for the other always still to come. Although this is a radical openness it is an openness within a greater dream (identification) with justice and democracy still to come, even in the knowledge that that dream (utopia) can never be accomplished as it will always remain a dream (u-topia), a non-place, like the messiah who will never come, or a messianism without Messiah.

This messianism without Messiah can be contrasted with a radical Christian version of the Messiah who has come. The Christ Advent has happened. The Advent of the incarnation has happened and thus the absolutely Other, who is every other according to Derrida, (Derrida 1995:76) has become immanent. Every other is wholly other, the Ding-an-sich (Other), yet in Christianity this wholly Other has manifested itself and revealed itself completely (incarnated) for-us in Jesus of Nazareth. The transcendental has become immanent. The Word has become flesh, the Logos has become matter, theory has become practice. These old duels have become, as Laruelle (1999:140) says, a unilateral duality, or a Visionin-One. Even if, from Derrida's and Laruelle's point of view it is in the exact opposite direction, matter (flesh) has become word/text/thought, the point is, there is no more transcendental. With this radical statement Derrida and Laruelle do not deny that there is a Ding-an-sich that is unknown, but what Derrida denies is that one can have access to this Ding-an-sich without writing. What Laruelle argues is that both writing and the other are given and thus they are identical in immanence in-the-last-instance. Thus any contemplation, thinking, writing, statement about the unknowable Ding-an-sich is a thought and thus it is givenwithout-givenness just as much as writing is given-withoutgivenness, and in that sense they are identical in-the-lastinstance (Laruelle 1999:143). Therefore the One and the Other are given in-One or Vision-in-One.

Thus all the old duels are given-in-One (vision-in-One) as they are unifacially turned towards not some transcendental Other, but together face the future (Laruelle 2011:254). Therefore it is no longer the bifacial situation of various duels between theory and practice, immanence and transcendence, but it is a Vision-in-One unifacially turned to the future as adventus beyond prediction. This is crucial for Practical Theology, as the discipline of Practical Theology has been defined and shaped in its history by the various interpretations concerning the relationship between the theory-practice duel. Browning's (1991) influential book postulated this relationship as theory-laden-practice which he developed from Tracy's critical correlational model, but in all these various forms of correlation, critical or not, there remains a difference that eventually forms an identity or synthesis on a meta-level or overview level as Laruelle (2010) argues, and so it remains idealism as either theoreticist idealism or idealist theoreticism (Laruelle 2003:173). For Laruelle every philosophy is bound to a specularity that it mistakes for the real. ${ }^{1}$ These different Practical Theological approaches (theories) about the duel between theory and practice remain exactly what Browning so desperately wanted to avoid a linear approach of idealism's determination of the real.
In this determination of the real, power always plays an important role and therefore the injustice or violence of knowledge inflicted on the real. Quentin Meillassoux (2008) in After finitude, opposes this correlationism with radical contingency. I will not follow Meillassoux as I believe that he does not escape correlationism, but remains himself caught in its web, but rather follow Laruelle and later combine Laruelle's thoughts with the ancient Byzantine holy fools, specifically those described by the hagiographers as salos (Thomas 2009).

I will seek to unpack Laruelle's non-philosophy in the light of the blasphemous heresy of the Christ narrative with its three moments of incarnation, crucifixion and resurrection as an Easter-Pentecost advent.

The Gospels begin with the radical heresy of Christ's birth in Bethlehem. God, the Ding-an-sich par excellence, in the Kantian sense that God cannot be known an-sich, but only as God has revealed for us. God cannot be known by any rational capabilities on our part, thus God is absolutely foreclosed to any rational abilities humans might have. Barth and Luther both strongly opposed the possibility of any form of natural theology. The only access that humans have to God is through the self-revelation of God in Christ - the Ding-an-sich made immanent (flesh). Therefore God, the unknowable Other, becomes knowable in Christ alone, but not in the sense of a sign signifying a referent, but I will argue rather like Laruelle's radical-hyle as a non-conceptual symbol (Brassier 2001:267f). Jesus himself argues that if the disciples want to know the Father they must know him. There is no way to God besides through Him (Jn 14:6). God, the unknowable Other, becomes Christ for-us.

The incarnation is already a blasphemous thought for any religious mind, but also for any philosopher who needs the duel of some form or other of correlation. Thus Christ becomes folly to the philosophers seeking duels, and for the Jews who seek signs and not a radical-hyle (non-conceptual symbols) Christ becomes a stumbling block (1 Cor 1:22-23). Jews want signs and philosophers want duels and Christianity offers neither, rather offering Logos made flesh as a given without givenness (see Laruelle 2000:185): God made human. This incarnation is not on the basis of some or other philosophical theory or technology of knowledge, but it is axiomatically posited to be accepted in faith by grace alone. Nor is Christ a sign that points to some other, but $\mathrm{He}$ is a non-conceptual symbol: God is Jesus! Christ-God is an identification in-thelast-instance - not on the basis of some theory or decision nor an identification of reference as in a sign (supplement).

Thus the Greeks (philosophers) who seek universal transcendental theory (idealism) see this non-philosophy, nonduelism, non-correlationism as folly. For the Jews in their turn who seek particular signs of the particular chosen of universal (absolute), this singular universal is a stumbling block.

This incarnation is radicalised even more on the cross and the death of God or the forsakenness of God in the cry of Jesus on the cross (see Žižek 2012:164-170). 
The radical immanence of Christ needs to be appreciated: there is no outside text, there is no transcendental:

The suffering of God and the suffering of human subjectivity deprived of God must be analysed as the recto and verso of the same event. There is a fundamental relationship between divine kenosis and the tendency of modern reason to posit a beyond which remains inaccessible. The Encyclopaedia makes this relation visible by presenting the Death of God at once as the Passion of the Son who 'dies in the pain of negativity' and the human feeling that we can know nothing of God. (Malabou 2005:103)

The dividedness within God-self is no longer the dividedness of One as opposed to the Other, but the dividedness of Godself within God-self. It is the death of God within God, within the One, thus the difference and the One are given-in-One, vision-in-One and thus no longer a duel, but a unilateral duality as Laruelle (1999) refers to it. Žižek argues that this should not be confused with the pagan and New Age ideas of unity in diversity or unity of opposites ${ }^{2}$, but rather God is the greatest rebel against Himself and He carries this antagonism within Himself (see Žižek 2009:47) and this is the unique contribution of Christianity: the redoubling of alienation ${ }^{3}$ and that God bears the pain of this double alienation, or double kenosis that is unique to Christianity (see Žižek 2009:48, 55). This has certain parallels to Laruelle's radicalhyle as a non-conceptual symbol, as the first name of matter itself, as mentioned above. For Hegel, what happened on the cross is the dying of both the Absolute (God-in-himself) as well as God-for-us in Christ, thus both the Father and the Son die on the Cross and this is aufgehoben in the sending of the Holy Spirit (see Malabou 2005:107). The Holy Spirit is not the universal a-temporal Spirit, because that would miss the point of the incarnation in the first place, but the Spirit's only site of actualisation is in human subjects: the body of believers (church). This is the radical beauty of God's love - that God binds God-self to the church. There is no God beyond the church. Church understood broadly as the community of believers where faith, hope and love are actualised as the gifts of the Spirit, or as Jesus says: 'I am present where two or three are gathered in my name' (Mt 18:20). Therefore, the Triune God becomes present (is actualised) in the subjective belief of the believers:

This means that in spite of all its grounding power, Spirit is a virtual entity in the sense that its status is that of a subjective presupposition: it exists only insofar as subjects act as if it exists. (Žižek 2009:56)

2.'God is not only not the "unity of opposites" in the sense of one pole (the good One - encompassing its opposite, using evil, struggle, difference in general, as means to enhance the harmony and wealth of the All. It is also not enough to say that he is the "unity of opposites" in the sense of being himself "torn" between the he is the "unity of opposites" in the sense of being himself "torn" between the opposite forces. Hegel is talking about something much more radical: the "unity
of the opposites" means that, in self-reflexive short circuit, God falls into His own of the opposites" means that, in self-reflexive short circuit, God falls into His own
creation; that, like the proverbial snake, He in a way shallows/eats Himself by His creation; that, like the proverbial snake, He in a way shallows/eats Himself by His
own tail. In short, the "unity of the opposites: does not mean that God plays with own tail. In short, the "unity of the opposites: does not mean that God plays with
Himself the game of (self-)alienation, allowing evil opposition in order to overcome it and thus assert its moral strength, and so on. It means the "God" is a mask (a travesty) of "Devil," that the difference between Good and Evil is internal to Evil" (Žižek 2009:45-46).

3.Referring to Hegel, Žižek argues 'The only solution is, as we have already seen, the very redoubling of alienation, the insight into how my alienation from the Absolute overlaps with the Absolute's self-alienation: I am "in" God in my very distance from him. The crucial problem is, how are we to think the link between these two "alienations" the one of the modern man from God (who is reduced to an unknowable In-itself, absent from the world subjected to mechanical laws), the an unknowable In-itself, absent from the world subjected to mechanical laws), the
other of God form Himself (in Christ, incarnation) - they are the same, although not other of God form Himself (in Christ, incarnation) - they ar
symmetrically, but as subject and object' (Žižek 2009:55).
God binds Himself completely to the church:

What is sublated in the move from the Son to Holy Spirit is thus God Himself: after crucifixion, the death of the incarnated God, the universal God returns as a Spirit of the community of believers, that is, HE is the one who passes from being a transcendent substantial Reality to a virtual/Real entity which exits only as the 'presupposition' of acting individuals. (Žižek 2009:57)

Easter-Pentecost is the absolute performativity of this radicalhyle, the subjectivisation (Spirit descending) on the apostles and the birth of the church, through the performativity of the faith of the believers received by grace alone as a gift given without givenness. The church is born as a community of people where the Word is performed both in the preaching of the Gospel as well as in the breaking of the bread. Thus the Spirit becomes actual only in the subjective performativity of the communities of believers presupposing the Spirit in the act of faith by grace alone.

Therefore this new community is no longer a correlational community, but a Vision-in-One turned unifacially towards the unknown future not as transcendental, but as already given in the Advent of Christ' incarnation and crucifixion, given in the performativity of the Word, given in the Word made bread and wine in the time that remains.

This unifacially turned towards the immanent future given in Christ that will reveal all our seeing as blindness ${ }^{4}$, reminds one of the salos, Byzantine holy fools (see Thomas 2009), who incarnate this exposedness, incarnate this being a stranger in the world, who incarnate radically the idea of living by grace and faith alone and thus rejecting any technologies of knowledge (see Thomas 2009:129). They reject the duels between theory and practice, immanence and transcendence, idealism and materialism and one could arguably opt for what Laruelle calls a vision-in-One or a radical understanding of Christ's incarnation and double alienation sublated in the sending (actualisation) of the Holy Spirit through faith by grace alone. The holy fools, not embedded in technologies of knowledge or sufficient philosophy but embedded in the radicalness of faith and grace alone, unifacially turned towards the unknown future living the folly of Christ alone. Not radically facing the Other who is sublated into an identity of the same at a meta-level but being radically open to the unknown future is folly and exposes the folly of all that is in the name of that unknown future.

4 'God is not hidden to us: He is revealed. But what and how we shall be in Christ, and what and how the world will be in Christ at the end of God's road, at the breaking in of redemption and completion, that is not revealed to us; that is hidden. Let us be honest: we do not know what we are saying when we speak of Jesus Christ's coming again in judgement, and of the resurrection of the dead, of eternal life and coming again in judgement, and of the resurrection of the dead, of eternal life and seeing, compared to which all our present vision will have been blindness - is too often testified in Scripture for us to feel we ought to prepare ourselves for it. For we do not know what will be revealed when the last covering is removed from ou eyes, form all eyes: how we shall behold one another and what we shall be to one another - men of today and men of the past centuries and millennia, ancestors and descendants, husbands and wives, wise and foolish, oppressors and oppressed traitors and betrayed, murderers and murdered, West and East, Germans and others, Christians, Jews, and heathen, orthodox and heretics, Catholics and Proter, Chrs intics and Protestants, lis confrontations and cross-connections the seals of all books will be opened; how much will only then appear great and important; for what surprises of all kinds we we have lived and still live here and now, will be for us then; what the constellations, the sea, the broad valleys and heights, which we see and know now, will say and mean then' (Barth 2003:45-46). 
This has certain consequences for Practical Theology if theory and practice are identical in the last instance and can no longer be seen as being in a duel or a correlation:

Non-philosophy is at once a theoretical practice and a performative theory. Moreover, it is precisely in so far as the non-philosopher is already operating according to immanence as 'already performed' that he or she cannot help but say what he/she does and do as he/she says. (Brassier 2003:31)

Thus theory and practice are seen in-One, they are an identity in-the-last-instance. They are both radically immanent and as such they are unifacially turned (estranged) towards the future. This has consequences for practical theological thinking by taking the Lacanian not-knowing position of vulnerability to another level and not seeking to master the discourse of either the pastoral situation or the congregational situation, but being a holy fool and as such being nothing more than an instrument of grace and transformation without having any idea of transformation towards what. This is a radically immanent subjectivity, a stranger-subject (see Laruelle 2003:179) a holy fool and truly: soli Deo Gloria - no longer added as a pious statement, but a performative utterance.

\section{Acknowledgements Competing interests}

The author declares that he has no financial or personal relationship(s) which may have inappropriately influenced him in writing this article.

\section{References}

Alkon, G. \& Gunjevic, B., 2011, 'According to the Identity of the Real: The nonphilosophical thought of immanence', Synthesis philosophica 51(1), 209-227.

Barth, K., 2003, God Here and now, Routledge, New York.

Brassier, R., 2001, 'Alien Theory: The decline of materialism in the name of matter', $\mathrm{PhD}$ thesis, Department of Philosophy, University of Warwick.

Brassier, R., 2003, 'Axiomatic heresy: The non-philosophy of François Laruelle', Radical Philosophy 121, 24-35
Browning, D., 1991, A Fundamental Practical Theology: Descriptive and Strategic Proposals, Fortress Press, Minneapolis.

Caputo, J.D., 1993, Demythologizing Heidegger, Indiana University Press, Indianapolis. Derrida, J., 1982, Margins of philosophy, transl. A. Bass, Harvester, Brighton.

Derrida, J., 1995, 'Sauf le nom', in J. Derrida \& T. Dutoit (eds.), On the name, transl. D. Wood, J.J. Leavey \& I. McLeod, pp. 35-88, Stanford University Press, Stanford.

Derrida, J., 1997a, Of Grammatology, transl. G.C. Spivak, John Hopkins Press, Baltimore. Derrida, J., 1997b, The Politics of Friendship, transl. G. Collins, Verso, London.

Derrida, J., 2002, "Faith and knowledge: The two sources of "religion" at the limits of reason alone', in G. Anidjar (ed.), Acts of Religion, transl. J.F. Graham, pp. 40-101, Routledge, New York.

Lacan, J., 1991, 'The Other Side of Psychoanalysis', The seminar of Jacques Lacan, Book XVII 1969-1970, transl. R. Grigg, unpublished manuscript.

Laruelle, F., 1999, 'A summary of non-philosophy', Pli: The Warwick Journal of Philosophy 8, 138-148.

Laruelle, F., 2000, 'Identity and Event', Pli: The Warwick Journal of Philosophy, Parallel Processes 9, 174-189.

Laruelle, F., 2003, 'What can non-philosophy do?', transl. R Brassier, Angelaki: Journal of the Theoretical Humanities 8(2), 169-189. http://dx.doi.org/10.1080/ 0969725032000162648

Laruelle, F., 2010, Philosophies of Difference: A Critical Introduction to non-philosophy, transl. R. Gangle, Continuum, New York. (Kindle edition).

Laruelle, F., 2011, 'The generic as predicate and constant: non-philosophy and materialism', in L. Bryant, N. Srnicek \& G. Harman (eds.), The Speculative Turn: Continental Materialism and Realism, pp. 237-260, re.press, Melbourne.

Malabou, C., 2005, The future Hegel, Routledge, New York.

Meillassoux, Q., 2008, After finitude: An essay on radical contingency, transl. R. Brassier, Continuum, New York.

Schrag, C.O., 1992, The Resources of rationality: A response to the postmodern challenge, Indiana University Press, Indianapolis.

Serres, M., 1982, Hermes: Literature, science, philosophy, The John Hopkins University Press, Baltimore.

Thomas, A., 2009, 'The Holy Fools: A theological inquiry', PhD Thesis, Department of Theology, University of Nottingham.

Welsch, W., 2008a, 'Reason and Transition; on the concept of transversal reason, from Prof. Dr. Wolfgang Welsch online texts and Publication abstracts', viewed 07 May 2012, from http://www2.uni-jena.de/welsch/

Welsch, W., 2008b, 'Rationality and Reason today, from Prof. Dr. Wolfgang Welsch online texts and Publication abstracts', viewed 07 May 2012, from http://www2. uni-jena.de/welsch/

Žižek, S., 2006, The Parallax View, The MIT Press, London.

Žižek, S., 2009, 'From Job to Christ: A Paulinian reading of Chesterton', in J.D. Caputo \& L.M. Alcoff (ed.), St. Paul among the philosophers, pp. 39-58, Indiana University Press, Indianapolis.

Žižek, S., 2012, 'Only a suffering God can save us', in S. Žižek \& B. Gunjevic (eds.), God in Pain, pp. 155-192, Seven Stories Press, New York. 